\title{
Teachers Learning about Teaching Practice in a Modify Lesson Study
}

\author{
Nisakorn Boonsena1, Maitree Inprasitha ${ }^{2}$, Narumon Changsri², Gabriel Matney ${ }^{3}$ \\ ${ }^{1}$ Doctoral Program in Mathematics Education, Faculty of Education, Khon Kaen University, Khon Kaen, Thailand \\ ${ }^{2}$ Center for Research in Mathematics Education, Khon Kaen University, Khon Kaen, Thailand \\ ${ }^{3}$ Bowling Green State University, Bowling Green, OH, USA \\ Email: nisabo@kku.ac.th, inprasitha_crme@kku.ac.th,changsri_crme@kku.ac.th,gmatney@bgsu.edu
}

How to cite this paper: Boonsena, N. Inprasitha, M., Changsri, N., \& Matney, G. (2019). Teachers Learning about Teaching Practice in a Modify Lesson Study. Psychology, 10, 977-988.

https://doi.org/10.4236/psych.2019.107064

Received: May 10, 2019

Accepted: June 18, 2019

Published: June 21, 2019

Copyright (c) 2019 by author(s) and Scientific Research Publishing Inc. This work is licensed under the Creative Commons Attribution International License (CC BY 4.0).

http://creativecommons.org/licenses/by/4.0/

(c) (i) Open Access

\begin{abstract}
Developing innovations in teaching and learning mathematics by focusing on the process of developing and sharing good practices was more important than importing good practice from other places (Inprasitha, Isoda, Wang-Iverson, \& Yeap, 2015b). Similarly, the Lesson Study project in Khon Kaen University and the $(\mathrm{CO})^{2} \mathrm{MP}$ Elementary project in the United States seek to engage practicing teachers in developing their instruction of mathematics through Lesson Study incorporating Open Approach (Inprasitha, 2010) rather than giving them prescribed sets of curriculum to teach. The study examines the teaching practices and learning of teachers in Thailand and the United States as they participated in a modify Lesson Study within their respective schools. Participants included teachers in the Lesson Study Project conducted by Center for Research in Mathematics Education, Khon Kaen University, Thailand and teachers in the Lesson Study Project conducted through the $(\mathrm{CO})^{2} \mathrm{MP}$ Elementary grant, Bowling Green State University, the United States. Method: a qualitative research design was used in this study. Data were collected by observations, interviews developed by Changsri (2012). Analysis: interviews were recorded and transcribed. The text from the observation notes and the interviews were considered together and coded for components of teaching practice and teachers learning about teaching practice. These codes were divided into evidence about teaching practice, lesson study systems, or evidence about teachers learning about the effect of lesson study based on Changsri (2012), Inprasitha (2010), and Matney (2014). The results reveal that 1 ) the components of teaching practice in a modify Lesson Study in Khon Kaen, Thailand and Ohio, United States were found to be similar and consisted of a lesson study team, teaching practices, and support, despite large differences in context and set up. The preparation and adaptation of each component in each context are very important, 2) teachers in Thailand
\end{abstract}


and the United States who participated in a modify Lesson Study had many changes in their learning.

\section{Keywords}

Lesson Study, Teachers Learning, Teaching Practice, Qualitative Research, Observation, Interview

\section{Introduction}

The purpose of professional development is not only to help teachers gain knowledge and understanding for teaching but also support them in acquiring proficiency in applying all knowledge and understanding in their classrooms (Takahashi, 2015). It is clear that most valued teaching and learning take place implicitly in the classroom (Bishop, 2015). Unfortunately, in most countries around the globe, school teachers have been ignored to do practices undesirable or without any useful instead of encouraging them to participate in a community of practice that useful for them and their students (Inprasitha, 2015c). Most teacher professional development programs are short term, lack innovation, outside of school training, and had disconnections between theory and classroom practice (Inprasitha, 2006, 2017a; Takahashi, 2015). Traditional classroom teaching practice might be improved by professional development consisting of short course training focused on training for improvement of mathematics contents (Inprasitha, 2015c). However, Lesson Study as envisioned by the teaching professions in Japan and developed more than 140 years ago, is differenced in their focus and professional development methods. Lesson Study focuses on student learning in the classroom, live classroom, teaching and observation, teacher learning, and school-based development (Inprasitha, 2017b). Lesson Study was accepted as a main method of professional development for Japanese teachers (Fujii, 2016; Inprasitha, 2006; Lewis, 2016; Shimizu \& Chino, 2015; Takahashi \& McDougal, 2016). It is currently an important method in a pre-service education for new teachers and in-service professional development for licensed teachers in Japan (Shimizu, 2006; Shimizu \& Chino, 2015). Lesson Study came to the attention of international educators and researchers through the publication of The Teaching Gap, the well-known book of Stigler and Hiebert in 1999, which described findings from the TIMSS video study focusing on the eighth grade mathematics lessons in USA, Germany, and Japan. In chapter seven in this book, Stigler and Hiebert described Lesson Study for Japan's structured problem-solving in mathematics, and Lesson Study as Japan's approach to the improvement of classroom teaching (Fujii, 2016; Inprasitha, 2003, 2010; Lewis, 2016; Shimizu \& Chino, 2015). Therefore, the teaching profession which focusing on students' problem solving might be developed by the teaching profession which is doing lesson study (Inprasitha, 2015c). 


\section{A Modify Lesson Study}

Stigler and Hiebert (1999) explained that in lesson study, group of teachers meet regularly over long periods of time (ranging from several months to a year). Steps in the Japanese lesson study process are as follows: 1) Defining the problem, 2) Planning the lesson, 3) Teaching the lesson, 4) Evaluating the Lesson and Reflecting on its effect, 5) Revising the lesson, 6) Teaching the revised lesson, 7) Evaluating the and Reflecting again, and 8) Sharing the results. Furthermore, there are several educators and researchers across the globe that study and describe Lesson Study. For instance; Baba (2007) described Lesson Study as the process in which teachers work together to improve their own teaching practices. Lesson Study includes preparation, teaching in a class with students, and review/reflection of the teaching event. Isoda (2015) explained the Lesson Study Cycle as having three parts: Plan (preparation of the lesson), Do (teaching and observation: Open Class), and See (Post open class discussion and reflection with perspectives from others). Moreover, Lewis $(2002,2016)$ described the Lesson Study Cycle in four steps: 1) study curriculum and teaching materials, consider long-term goals for students; 2) plan a research lesson/unit and anticipate student thinking; 3) teach the research lesson and collect data; and 4) reflect on lesson data and implications for teaching-learning. Fujii (2016) explained that the Lesson Study cycle had five steps: 1) Goal setting: consider long-term goals for student learning and development; 2) Identify the research theme: Lesson planning; collaboratively plan a "research lesson" designed to address the goals. Prepare a lesson plan that describes the research theme, content goals, anticipated student thinking, data collection; 3) Research lesson: one team member teaches the research lesson while the other members of the planning team, staff members from across the school, and, usually, an outside knowledgeable other observe and collect data; 4) Post-lesson discussion: in a formal lesson colloquium, observers share data from the lesson to illuminate student learning, disciplinary content, lesson and unit design, and broader issues in teaching and learning; 5) Reflection: document the cycle to consolidate and carry forward learnings, as well as new questions for the next cycle of Lesson Study.

Inprasitha (2003) implemented Japanese teaching professionalism in Thailand by focusing on teachers work together in order to improve teaching practice in the classroom continually. The heart of this teaching professionalism was the classroom; we can also call this "classroom study" (Inprasitha, 2017b). Inprasitha $(2003,2006,2010,2015 b, 2017 c, 2018)$ described Lesson Study conducted in Thailand as having a weekly cycle which includes three phases: 1) Collaboratively design research lesson (Plan), teachers collaboratively designed problem situations, once a week; 2) Collaboratively observing research lesson (Do), teacher taught by using Open Approach in classes and; 3) Collaboratively enacting a post-discussion or reflection about the teaching practice (See). In this model the school principal reflected with the Lesson Study team and other teachers, once a week (Whole school approach). Moreover, this Lesson Study was incorporating 
Open Approach. An Open Approach was a teaching approach that had four steps according to Inprasitha (2003, 2006, 2010, 2015b, 2017c, 2018): 1) Posing an open-ended problem such as a tasks or problem situation that was within the students' real world context; 2) A time of students' self-learning through solving the problem for themselves while the teacher observed and took notes about students' ideas or ways of thinking; 3) Teacher orchestrated students to do whole-class discussion and comparing students' representations, reasoning, and connections; and 4) Teacher facilitated summarizing student's ideas that emerged during instruction focusing on mathematical ideas such as generalization and extension. The teacher encouraged the students to take notes as "my ideas", "friends" ideas", and "new ideas for today" (Figure 1).

In addition, Matney (2014) and Matney \& Lane (2016) implemented Open Approach Lesson Study in Ohio, the United States included four steps: 1) Grade level teacher team researches ideas and writes a lesson plan together, 2) One teacher teaches the lesson to a class while the team observes, taking vigorous notes, 3) The team of teachers reconvenes to share observations and reflect on how to improve the lesson, and 4) Teacher team reflects on the whole lesson study cycle (Figure 2).

Beginning to do lesson study in a school was not an easy task. One of the major issues that accounts for a Lesson Study program to be sustainable for introducing new ideas or new innovations was proper preparation (Inprasitha, 2015a). Furthermore, as Takahashi (2015) mentioned teachers need to learn new ideas and knowledge to improve teaching and learning. At the same time teachers also need to have opportunities to try those ideas and use new knowledge in their classrooms and reflect upon how the ideas and knowledge contribute to the quality of students learning experience. Lesson study provides teachers with opportunities to try new ideas in their own classroom. In additional, teacher learning

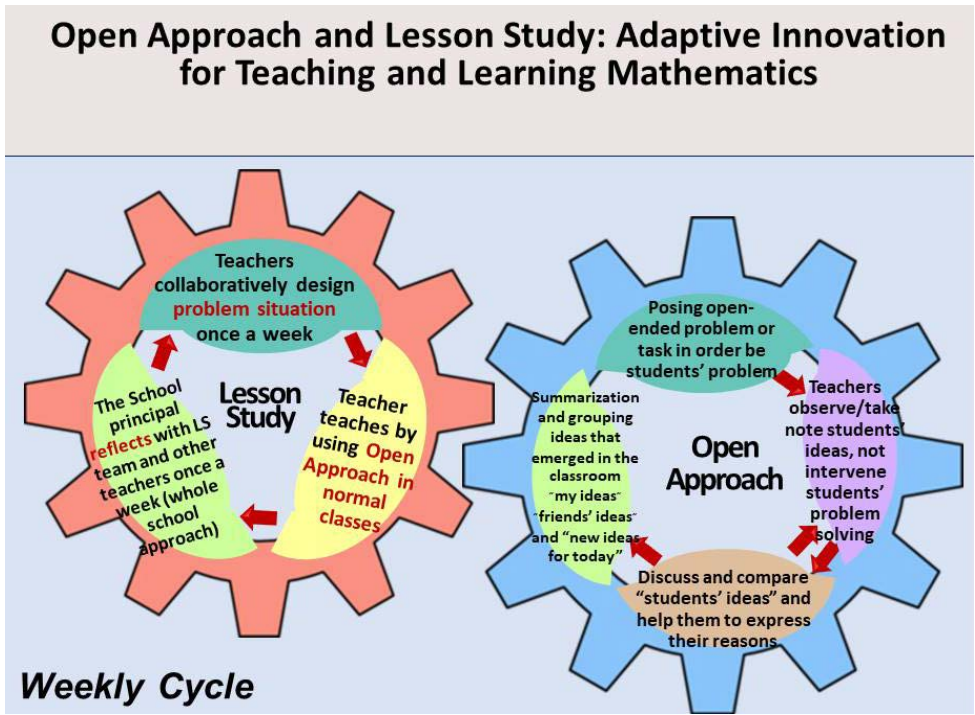

Figure 1. The weekly cycle of Open Approach Lesson Study (Inprasitha, 2003, 2006, 2010, 2015b, 2017c, 2018). 


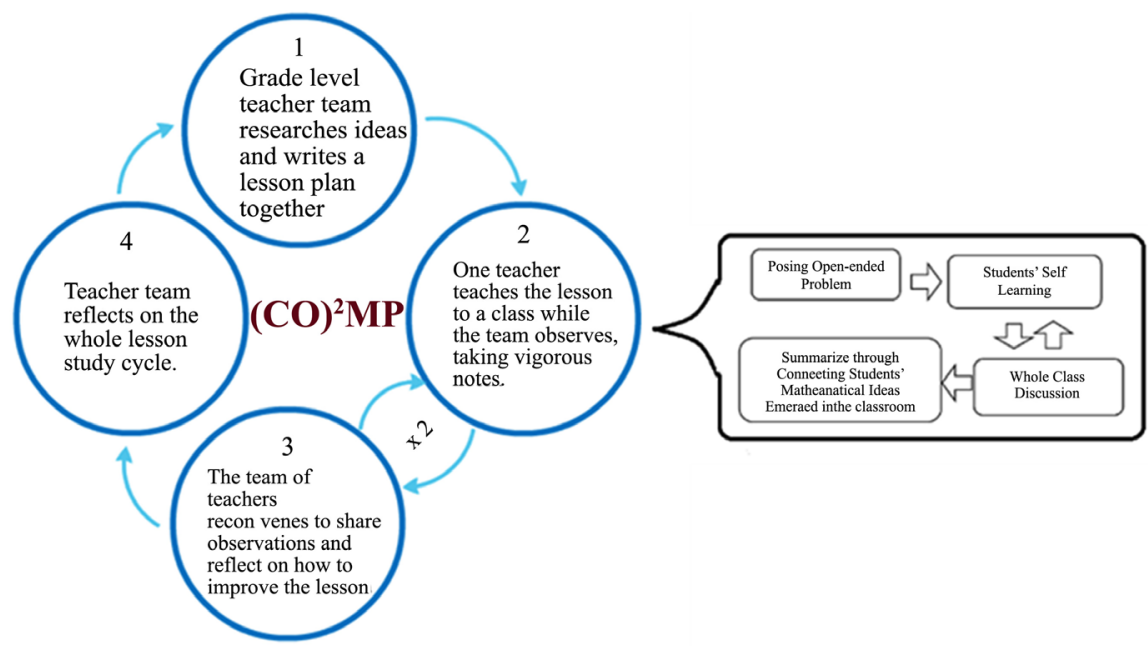

Figure 2. Lesson study process (Matney, 2014; Matney \& Lane, 2016).

as the member of the professional learning community different from learning through the short course training because the new learning is from teachers' awareness about their improvements of classroom teaching practices from the empirical evidences of their students' thinking and learning in the classroom (Inprasitha, 2017b). Therefore, teacher learning in the two modify lesson study contexts are of interest.

\section{Context of Study}

There is an APEC-Lesson Study project that proposed by Office of the Higher Education Commission, Ministry of Education, Thailand and Ministry of Education, Culture, Sports, Science and Technology, Japan and organized by Khon Kaen University, Thailand and University of Tsukuba, Japan sine 2006 until present. The project aims to develop innovations in teaching and learning mathematics by focusing on the process of developing and sharing good practices instead of importing good practice from other places (Inprasitha, Isoda, Wang-Iverson, \& Yeap, 2015b). Similarly, the (CO $)^{2}$ MP Elementary project in the United States seeks to engage practicing teachers in developing their instruction of mathematics through Open Approach Lesson Study rather than giving them prescribed sets of curriculum to teach. Teachers in the project are prompted to make-sense of their beliefs, their students' learning and their curriculums by engaging in a professional learning community meant to improve and share ideas with the larger teaching community. The similar nature of these projects, in the context of two difference countries makes exploration of the teaching and practice and teacher beliefs a unit of interest for research.

\section{Methodology}

The objectives of this study are 1) to investigate teaching practice based on Lesson Study, and 2) to investigate teachers learning about their teaching practice based on Lesson Study. 
Participants are the teachers in the Lesson Study Project conducted by Center for Research in Mathematics Education, Khon Kaen University, Thailand and teachers in the Lesson Study Project conducted through the (CO $)^{2} \mathrm{MP}$ Elementary grant, Bowling Green State University, the United States.

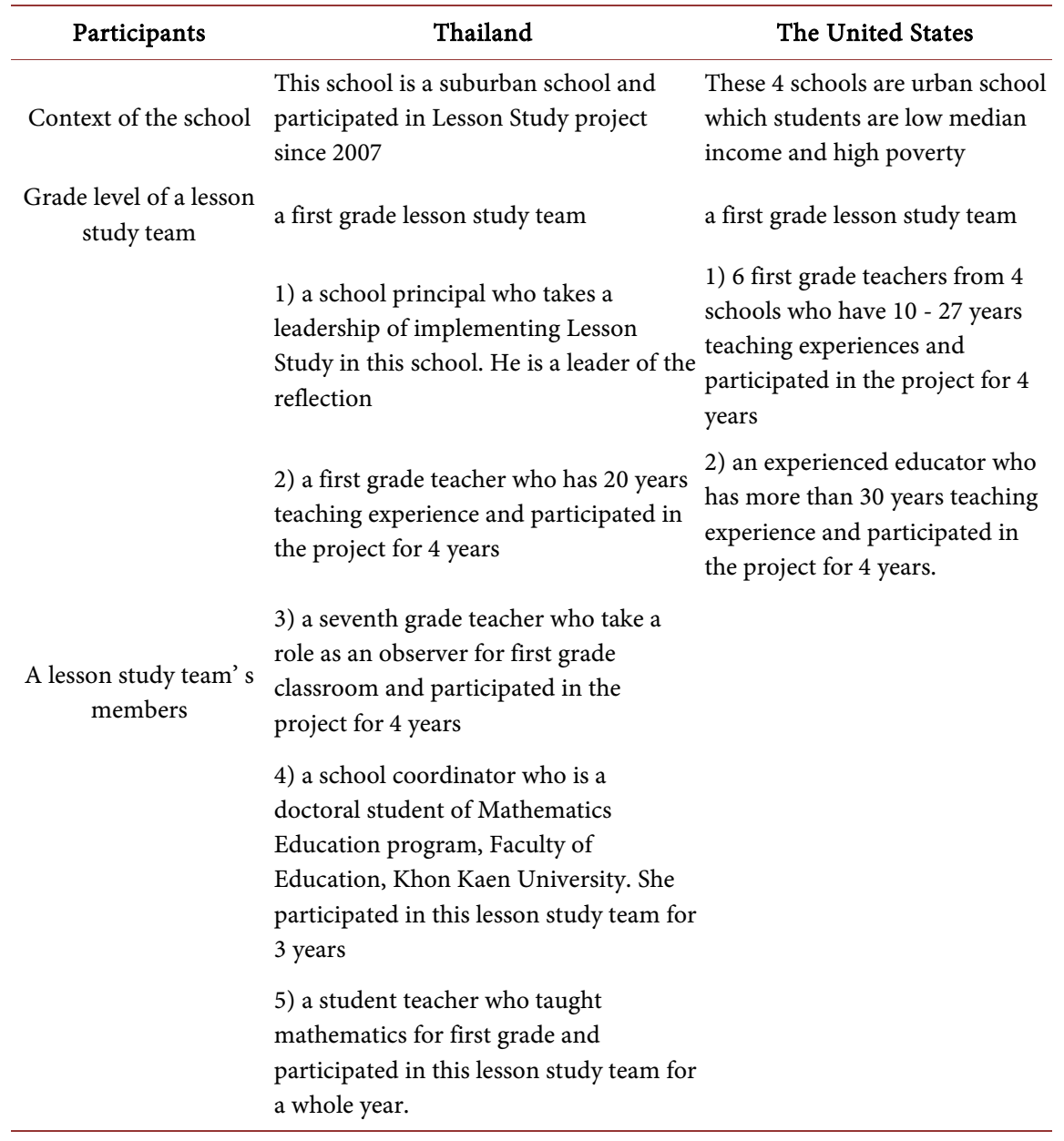

Method: the qualitative research design was used in this study. Data were collected by observations and, interviews protocols developed by Changsri (2012).

Observations: Occurred during the steps of Lesson Study including planning, teaching, and reflecting. The focusing points were who participated in each step, what they did, and what evidences that happened. The observation in Thailand was in 2010-2012 and in the United States was in 2016-2017.

Interviews: The interviewees were the teachers in first grade lesson study teams. The questions were asked in various issues. For example what kind of classroom teaching practices in traditional teaching approach and in the context of Lesson Study, and what changes occur among the teachers and students after implementing lesson study in schools (Teachers and students' mathematics behavior and knowledge, process/skills, and attitude).

Analysis: interviews were recorded and transcribed. The text from the observation notes and the interviews were considered together and coded for compo- 
nents of teaching practice and teachers' learning about teaching practice. These codes were divided into evidence about teaching practice, lesson study systems or evidence about teachers' learning effect of lesson study based on Changsri (2012), Inprasitha (2003, 2006, 2010, 2015a), Matney (2014) and Matney \& Lane (2016).

\section{Results}

\subsection{Lesson Study Process}

In Thailand, the team conducts Lesson Study by using a weekly cycle according with Inprasitha's idea (Changsri, 2012). The Lesson Study team consists of one first grade teacher (teacher/observer), and two first grade and second grade student teachers (teacher/observer). They work together every day. For other observers who are teachers in the school and school principal, they participate in lesson study team at least one day per week. Moreover, a graduate student from Khon Kaen University who works as a school coordinator, works with the lesson study team two to four days per week. Supervisors from Khon Kaen University work with a lesson study team one to two times per semester. The Lesson Study process follows a weekly cycle as follows (Changsri, 2012):

1) Collaboratively design are search lesson (Plan), lesson study team in each grade level plan the classroom lessons for whole week together on every Tuesday in the last period. They work to understand the textbook which had been translated from Japanese textbook into Thai. Using this textbook the teachers try to create a problem situation.

2) Collaboratively observing research lesson (Do), lesson study team teaches and observes the first grade mathematics classroom four times per week.

3) Collaboratively doing post-discussion or reflection on teaching practice (See), the school principal is the leader of the meeting. All lesson study teams reflect together from first grade team to the eighth grade team. The reflection by each team begins with student teachers, first grade teacher, observers, school coordinator, and school principal. This meeting is on every Thursday in the last period.

Moreover, there are one to two professional development workshops for teachers in each semester. Teachers also have opportunities to participate in the Open Class and APEC-ICER international conference.

In the United States, the Lesson Study team enacts the study over 2-days, 1 cycle per semester according to Matney (2014) and Matney \& Lane (2016). Lesson Study team consists of six first grade teachers from four schools, and one experienced educator. They work together for 2-days, 1 cycle per semester. For Supervisors from Bowling Green State University, they work with lesson study team one time per semester.

Lesson Study process follows a cycle per semester as following:

1) Grade level teacher team researches ideas and writes a lesson plan together. They plan the classroom lesson together two weeks before teaching. Supervisor and experienced educator also participate and support teachers to plan the lesson. 
2) One teacher teaches the lesson to a class while the team observes, taking vigorous notes about students' thinking. Before teaching, lesson study team has a review meeting. They talk about the lesson plan and make any last adaption to it based on feedback from a knowledgeable other. Then the first classroom begins.

3) The team of teachers reconvenes to share observations and reflect on how to improve the lesson. After teaching and observation in the first classroom, the lesson study team reflects on the lesson plan and students' ideas and then revises the lesson plan. Then the second or third classroom begins.

4) Teacher team reflects on the whole lesson study cycle. After two or three classes finish. Lesson study team reflects for the whole process.

In addition, there is one professional development workshop for teachers in every summer. Teachers also have opportunities to participate in many conferences to share their teaching practices through lesson study.

\subsection{Components of Lesson Study}

\begin{tabular}{|c|c|c|}
\hline Components & Thailand (Changsri, 2012) & The United States \\
\hline $\begin{array}{c}\text { Lesson } \\
\text { study team }\end{array}$ & $\begin{array}{l}\text { - at least } 2 \text { persons; teacher and observer } \\
\text { - in-service teacher or student teacher } \\
\text { - could be include school principal, } \\
\text { school coordinator, researcher, and } \\
\text { expert from the university }\end{array}$ & $\begin{array}{l}\text { - at least } 3 \text { persons; teacher, observer, } \\
\text { and experienced educator } \\
\text { - could be include expert from the } \\
\text { university } \\
\text { - no student teacher, school principal, } \\
\text { school coordinator, and researcher }\end{array}$ \\
\hline $\begin{array}{l}\text { Teaching } \\
\text { practices }\end{array}$ & $\begin{array}{l}\text { - Weekly, } 16 \text { cycles per semester } \\
\text { - plans taught \& revised each day of the } \\
\text { week } \\
\text { - lesson not retaught until next year }\end{array}$ & $\begin{array}{l}\text { - 2-days, } 1 \text { cycle per semester } \\
\text { - plans revised several times on LS day } \\
\text { - lessons are revised and retaught on } \\
\text { same day }\end{array}$ \\
\hline Support & $\begin{array}{l}\text { - School \& CRME supports materials and } \\
\text { financial costs }\end{array}$ & $\begin{array}{l}\text { - }(\mathrm{CO})^{2} \mathrm{MP} \text { Elementary grant supports } \\
\text { materials and financial costs }\end{array}$ \\
\hline $\begin{array}{l}\text { University } \\
\text { support }\end{array}$ & $\begin{array}{l}\text { - assign school coordinator and } \\
\text { researcher } \\
\text { - observing and supervision from expert } \\
\text { from university; assign student teachers } \\
\text { - support school to attend the educational } \\
\text { activities }\end{array}$ & $\begin{array}{l}\text { - } \text { assign experience educator } \\
\text { - give suggestion from expert from } \\
\text { university } \\
\text { - support teacher team to attend the } \\
\text { educational activities }\end{array}$ \\
\hline
\end{tabular}

\subsection{Teachers Learning about Teaching Practice}

After the first four years of doing a modify lesson study in Khon Kaen, Thailand and in Ohio, United States, teachers learning about teaching practice are as some examples from the open-ended questions as following:

\section{Thai teachers learning}

Mathematics Teaching:

Teacher: "Before attend the project, I like to have the quiet class. Students should listen to me. However, after join the lesson study project, I usually listen to students; give them an opportunity to explain their ideas".

Teacher: "I plan the lesson and prepare the materials. I use the reflections to revise my lesson plan and teaching. Teachers can learn from students' thinking”. 


\section{Mathematics Learning:}

Teacher: "Before this, my students are always quiet and only listen to me. But now, they can participate in the classroom. They discuss with the reasons and work as a team".

Teacher: "Students change to proud of their works, respect to their friends' ideas. They are happy for learning mathematics. They want to learn mathematics".

Social Context.

Teacher: "At the first year, I do not want to allow anybody to observe my class. I am very nervous. Now, I can talk with other teachers about my teaching. I can teach and have some teachers observed my class".

Teacher: "I take a lot of time to plan the lesson and prepare materials".

\section{US teachers learning}

\section{Mathematics Teaching:}

Teacher: "We realized that we need to let the students struggle to figure things out. We need to dig deeper rather than do more problems. We became better math teachers by practicing and watching our peers, and making changes to the lesson".

Teacher: "Open to more ways to solve problems".

\section{Mathematics Learning:}

Teacher: "The students enjoyed solving math problems. They are able to explain their thinking and ask questions of other students when they do not agree. Their mathematical thinking improved".

Teacher: "More interesting in learning, Could see them working 'harder' to master material, Loved their math 'voice"'.

\section{Social Context.}

Teacher: "I really like we got to work together. I really like able to observe other teacher teach the lesson and then meet, talk about the changes, and then go back and have someone teach".

Teacher: "I think back to the first year, it was really new. We were nervous. Now, I feel confidence about teaching math. I think probably a lot things that make me feel confidence were going to the session with supervisors to learn more about why I was doing. Because I had just learn as a kid, I never really, I was one of those people who always get the right answers, how teacher might told me how to do it but I maybe do not know why. So, I think even coming better understanding about math by myself will help me".

\section{Concluding Remarks}

The components of teaching practice in a modified Lesson Study in Thailand and the United States were found to be similar and consisted of a lesson study team, teaching practices, and support, despite large differences in context and set up. The preparation and adaptation of each component in each context are very important.

Lesson Study team, in Thailand, the important part is a weekly cycle and les- 
son study team is at least 2 persons: teacher and observer. These are a basic rule for doing lesson study (Changsri, 2012). Teachers do Lesson Study in their own school. It is very convenient for teachers to work together. Moreover, Khon Kaen University can send student teacher to the school. There are student teachers participating in the lesson study team to work with in-service teachers. In addition, in the first few years of beginning lesson study in school, Khon Kaen University sends a graduate student to do lesson study with lesson study team as school coordinator. It is beneficial for both graduate students and lesson study teams, because they can learn various perspectives of doing lesson study from each other. Lesson Study team, in the United States, teachers do lesson study among four schools for first grade lesson study team. There are six first grade teachers, and one experienced educator. They work together for 2-days, 1 cycle per semester. They re-teach in the same day. It provides the opportunity for teachers to learn from how to improve their instruction and planning for teaching.

Teaching practice, both teachers in Thailand and the United States focus on problem solving approaches to learning mathematics. Teachers in Thailand follow the steps of Open Approach, however, there are some parts that the lesson study team needs to understand and improve their teaching. For instance how to prepare the problem situation that is real world for students, how to connect students' thinking/ideas to mathematical way (Inprasitha, 2017c). On the other hand, teachers in the United States try to understand Open Approach. Now, they teach by focusing on problem solving. They would like to learn more about how to use Open Approach as a teaching approach.

Supporting is very important. Lesson Study is practicable because of the collaboration between school and university. The kind of supporting can be difference depend on context. However, the idea of working together is the main part. Lesson Study creates the community of practice for everyone (Changsri, 2012).

Teachers in Thailand and the United States who participated in the modified Lesson Study had many changes in their learning. The similarities include teachers spending more time to allow student understanding of the problem situation, the majority of time in the lesson was giving for student's problem solving, teachers found that students were confident and happy in learning, teachers felt confident and beneficial when they have the observers observe their classroom.

\section{Acknowledgements}

This research was supported by Research and Technology Transfer Affairs, Khon Kaen University. Funding for this research was provided in part by the Ohio Department of Education (Grant \# 016437). Any opinions, findings, conclusions, or recommendations expressed by the authors do not necessarily reflect the views of the Ohio Department of Education.

\section{Conflicts of Interest}

The authors declare no conflicts of interest regarding the publication of this paper. 


\section{References}

Baba, T. (2007). How Is Lesson Study Implemented? Japanese Lesson Study in Mathematics Its Impact, Diversity and Potential for Educational Improvement. Singapore: World Scientific Publishing. https://doi.org/10.1142/9789812707475_0001

Bishop, A. (2015). Mathematics Education for the Knowledge-Based Society. In M. Inprasitha, M. Isoda, P. Wang-Iverson, \& B. H. Yeap (Eds.), Lesson Study: Challenges in Mathematics Education (pp. 3-10). Singapore: World Scientific.

Changsri, N. (2012). Teacher's Perceived Beliefs about Teaching Practice in Teacher Professional Development Based on Lesson Study and Open Approach Context. Doctoral Dissertation, Khon Kaen: Khon Kaen University. (In Thai)

Fujii, T. (2016). Designing and Adapting Tasks in Lesson Planning: A Critical Process of Lesson Study. ZDM Mathematics Education, 48, 411-423.

https://doi.org/10.1007/s11858-016-0770-3

Inprasitha, M. (2003). Reforming of the Learning Process in School Mathematics: Emphasizing on Mathematical Processes. Khon Kaen: Khon Kaen Karnpim. (In Thai)

Inprasitha, M. (2006). Open-Ended Approach and Teacher Education. Tsukuba Journal of Educational Study in Mathematics, 25, 169-177.

Inprasitha, M. (2010). One Feature of Adaptive Lesson Study in Thailand-Designing Learning Unit. In Proceedings of the 45th Korean National Meeting of Mathematics Education (pp. 193-206). Seoul: Korean Society of Mathematics Education.

Inprasitha, M. (2015a). Preparing Ground for the Introduction of Lesson Study in Thailand. In M. Inprasitha, M. Isoda, P. Wang-Iverson, \& B. H. Yeap (Eds.), Lesson Study: Challenges in Mathematics Education (pp. 109-117). Singapore: World Scientific.

Inprasitha, M. (2015c). Lesson Study Incorporating Open Approach: Two Practices in Community of Practices to Improve Quality of Classroom. In World Association of Lesson Studies International Conference (pp. 1-81). Khon Kaen: Faculty of Education, Khon Kaen University.

Inprasitha, M. (2017a). Teacher Training System. In National Legislative Assembly (pp. 1-33). Bangkok: The National Legislative Assembly. (In Thai)

Inprasitha, M. (2017b). Booklet of the Workshop for Educational Personnel under the Project of Development of Students' Mathematics Higher-Order Thinking at North East of Thailand. Khon Kaen: Anna Offset. (In Thai)

Inprasitha, M. (2017c). Open Approach Lesson Study: An Innovation for Teaching Mathematics to Support STEM. In International STEM Education Conference (pp. 1-50). Chiang Mai: International STEM Education Conference.

Inprasitha, M. (2018). The Current Issues and Challenges in Teacher Education and Professional Development. In International Conference of the Korean Society of Mathematics Education (pp. 1-19). Seoul: International Conference of the Korean Society of Mathematics Education.

Inprasitha, M., Isoda, M., Wang-Iverson, P., \& Yeap, B. (2015b). Lesson Study: Challenges in Mathematics Education. Singapore: World Scientific. https://doi.org/10.1142/9789812835420_others01

Isoda, M. (2015). The Science of Lesson Study in the Problem Solving Approach. In M. Inprasitha, M. Isoda, P. Wang-Iverson, \& B. H. Yeap (Eds.), Lesson Study: Challenges in Mathematics Education (pp. 81-108). Singapore: World Scientific. https://doi.org/10.1142/9789812835420_0006

Lewis, C. (2002). Lesson Study: A Handbook of Teacher-Led Instructional Change. Philadelphia, PA: Research for Better Schools. 
Lewis, C. (2016). How Does Lesson Study Improve Mathematics Instruction? ZDM Mathematics Education, 48, 571-580. https://doi.org/10.1007/s11858-016-0792-x

Matney, G. (2014). Lesson Study Model. In Workshop for Teachers in the (CO)2 MP Elementary Grant (pp.1-4). Ohio: Bowling Green State University.

Matney, G., \& Lane, S. (2016). Lesson Study by Open Approach in the USA: A Comparison of Students' Mathematical Knowledge. In World Association of Lesson Study Conference (pp. 15-16). Exeter: The World Association of Lesson Studies (WALS).

Shimizu, S. (2006). Professional Development through Lesson Study: A Japanese Case. In APEC International Symposium on Innovation and Good Practices for Teaching and Learning Mathematics through Lesson Study. Khon Kaen: Center for Research in Mathematics Education.

Shimizu, S., \& Chino, K. (2015). History of Lesson Study to Develop Good Practices in Japan. In M. Inprasitha, M. Isoda, P. Wang-Iverson, \& B. H. Yeap (Eds.), Lesson Study: Challenges in Mathematics Education (pp. 123-140). Singapore: World Scientific. https://doi.org/10.1142/9789812835420_0008

Stigler, J. W., \& Hiebert, J. (1999). The Teaching Gap: Best Ideas from the World's Teachers for Improving Education in the Classroom. New York: Free Press.

Takahashi, A. (2015). Lesson Study: An Essential Process for Improving Mathematics Teaching and Learning. In M. Inprasitha, M. Isoda, P. Wang-Iverson, \& B. H. Yeap (Eds.), Lesson Study: Challenges in Mathematics Education (pp. 51-58). Singapore: World Scientific.

Takahashi, A., \& McDougal, T. (2016). Collaborative Lesson Research: Maximizing the Impact of Lesson Study. ZDM Mathematics Education, 48, 513-526.

https://doi.org/10.1007/s11858-015-0752-x 